International Research Journal of Management, IT \& Social Sciences
Available online at https://sloap.org/journals/index.php/irjmis/
Vol. 6 No. 2, March 2019, pages: 79 91
ISSN: 2395-7492
https://doi.org/10.21744/irjmis.v6n2.654

\title{
Revealing Ideology of Political Speech
}

\author{
David Samuel Latupeirissa ${ }^{\text {a }}$ \\ I Ketut Darma Laksana ${ }^{\text {b }}$ \\ Ketut Artawa ${ }^{c}$ \\ I Gusti Ayu Gde Sosiowati ${ }^{\mathrm{d}}$
}

Article history:

Received: 27 September 2018

Accepted: 31 January 2019

Published: 31 March 2019

\section{Keywords:}

discourse analysis; grounded theory;

ideology;

political language;

procedures;

\begin{abstract}
In this paper, we reflect on the ideology of political language delivered in political speech. We believe that language in political speech is a tool to spread hidden ideology. The impact of ideology can be positive, or it can also be negative for a nation. Our reflection deals with the revelation of ideology in the political speech text of the Indonesian politician, as well as Indonesian first president, Soekarno. Be based on grounded theory, we examined an important text of political speech that was delivered by Soekarno. The examination applied three main procedures to reveal ideology in text of political speech. The procedures are 1) by analyzing the main rhetorical devices that are used by the politician, 2) by analyzing the construction of the whole text, and 3) by reviewing the context of the situation and the background of the politician. As the results of applying the procedures, it was found that the ideologies of Soekarno's political speech were 'unity as the most important value for Indonesia', revolution as the soul of Indonesia' and, 'imperialism as the main enemy of Indonesia'. The ideologies are valuable for the Indonesia context todays because the nation itself is being threatened by radicalism ideology. The findings of those three main ideologies are novelty of this study. Besides, the current study also proposes three procedures for revealing ideology in a political language text as an enrichment for the future study of text.
\end{abstract}

2395-7492@ Copyright 2019. The Author. This is an open-access article under the CC BY-SA license (https://creativecommons.org/licenses/by-sa/4.0/) All rights reserved.

\section{Author correspondence:}

David Samuel Latupeirissa,

School of English Literature

STIBA Mentari Kupang, Indonesia.

Email address: latupeirissadavid1@gmail.com

${ }^{a}$ School of English Literature, STIBA Mentari Kupang, Indonesia

b Universitas Udayana Bali, Indonesia

c Universitas Udayana Bali, Indonesia

${ }^{\mathrm{d}}$ Universitas Udayana Bali, Indonesia 


\section{Introduction}

The study of political discourse has become a very crucial study, especially in the area of the ideology behind a political language. Thomans \& Wareing (1999), states that political speech, through indirect manipulation of language, impulses people to do or not to do something. Skillful speakers of political language are able to influence the preconceptions, views, ambitions, and fears of the public (Fairclough, 1989; 2001; 2007). They can persuade people to accept false statements as true postulates, or even support policies conflicting with their interests. Preconception, views, postulates, belief, etc, are parts of ideology that contain in political language (cf. McLellan, 1986; Erikson, \& Tedin, 2003).

The current study aim at revealing ideology of political speech. The ideology of political language can be a means of preserving or destroying a nation. It preserves a nation when politicians spread a positive ideology that is needed by the nation itself. In contrary, it destroys a nation when politicians use it as a means of grabbing power and authority for themselves without considering the truth and reality of their words.

\section{Why Indonesia?}

We conducted the study by reflecting the political speech of Soekarno as the founder of Indonesia. Indonesia, in our view, is a clear picture of a nation with 'political ideologies wars'. It is believed that the founders of Indonesia, included Soekarno, had planted Pancasilal as positive ideologies for Indonesia. Therefore the nation has been established and preserved. Unfortunately, facts have shown that nowadays, some Indonesian people are trying to destroy the ideologies and change it with ISIS and Khilafah Ideology (Mohamed, 2010; Liow, 2014; Jones, 2015; Galamas, 2015).

For example, there was $H T I^{2}$ with its contradiction values to the Indonesian state ideology, the Pancasila. HTI was likely to emerge as a key force challenging the state ideology of the Indonesian state. Therefore it has been banned ${ }^{3}$. Following is a figure that shows how people tried to reject government decision on banning HTI. The people supported HTI and stood for its ideology. This page should begin with the Introduction of your article and follow by the rest of your paper. Wilson (1990), stated that the Introduction explains the scope and objective of the study in the light of current knowledge on the subject.

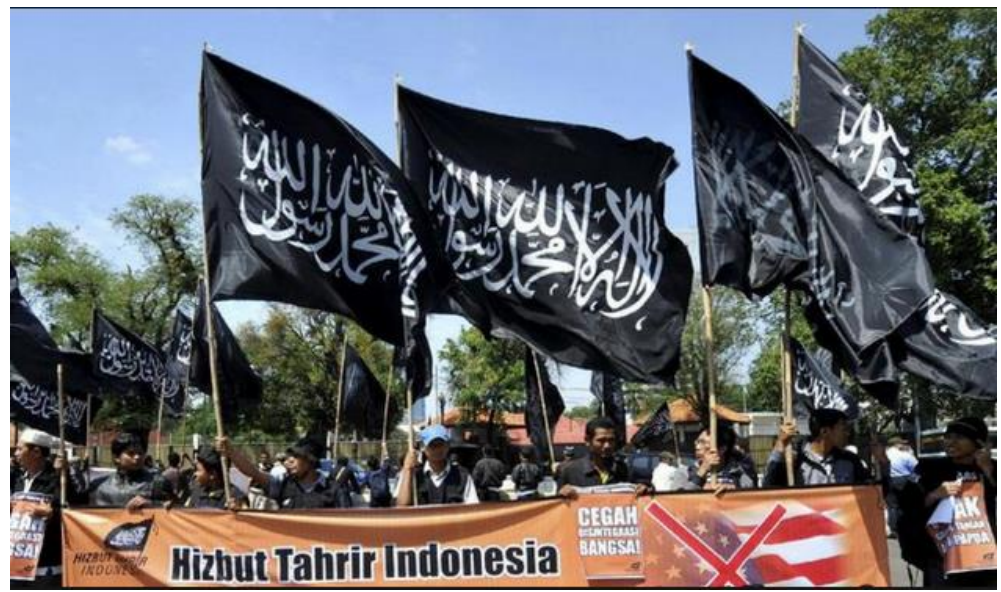

Figure 1. Some Indonesian People supported HTI

Source: https://breakingnews.co.id/read/hari-ini-ptun-akan-putuskan-nasib-hidup-hti-di-indonesia

The former leader of HTI stated that they still have a lot of supporters in Indonesia (Firmansyah, 2018). State Intelligence Agency of Indonesia stated that the organization of HTI and other Khilafah- secret- organizations ${ }^{4}$ are involved in the Indonesian political world (Arigi, 2019; Latupeirissa et al., 2018). It means that some Indonesian

${ }^{1}$ Pancasila is the Indonesia State Ideology which places national unity as its high value.

${ }^{2}$ An organization named Hizbut Tahrir Indonesia with Khillafah as their main ideology.

${ }^{3}$ However, it has ever existed for some years as legal organization in Indonesia. Furthermore, even though they have been banned, there are still remained terrorist cell as the impacted of the organization.

4 Terrorist secret organizations, included ISIS-based-ideology organizations. 
politicians are standing for un-pancasila ideology. Undeniable, their political ideology will destroy Indonesia. Through their political speech, they manipulate people to agree for Khilafah.

Furthermore, in Indonesia, where this study has been conducted on, most political languages have been viewed as a means to cheat people. the fact that the 'highest rate of corruption in Indonesia has acted by politicians' (Tim Penyusun Laporan Tahunan KPK, 2016) $)^{5}$ is a blow to the nation's social and political life. Indonesia scored 37 points out of 100 in 2017 (Corruption Perceptions Index, 2017). The Corruption Index in Indonesia averaged 25.79 points from 1995 until 2017. In the past, the political language, especially Soekarno Political Speech (SPS), was believed and accepted as a humane tool for the building and unifying of the nation. By way of contrast, nowadays, most political language is being used as a means to deceive people. It is a form of Pancasila political values erosion as well. The researchers believe that the phenomenon has not only occurred in Indonesia, but also in Western, Europe, and Africans countries. Counting such thoughts, the listeners of political speech have to realize the whatness and the whyness of a political speech. The real ideology behind the speech must be able to be uncovered by everyone.

Beside as a reflection, this paper was also written to propose some procedures for revealing ideology in political speech. The procedures proposed, are based on the examination of a political speech delivered by Soekarno ${ }^{6}$. Latupeirissa et al., (2018), have conducted research about Soekarno Political Language and found that Soekarno used language for the sake of Indonesian people. On their research, they applied the theory of Critical Discourse Analysis proposed by Fairclough, (1995, 2003, 2005, 2006). The Critical Theory and the findings were interested. However, they did not explain the step-by-step method of how they find the ideology behind the text. The methodology of finding the ideology behind the text was not clear. Related to previous research, we address a scientific question; how to reveal the ideology in political speech? Answering the question, we present the procedures, as well as show the results of applying the procedures.

\section{Materials and Methods}

The main research methods adopted in this paper are document research and textual analysis. In order to answer the question 'how to reveal ideology in political speech' and to draw reflection, we examined a political speech of Soekarno. The analysis was the basic thoughts to gain some procedures for revealing ideology behind the political speech. All data were taken from a corpus of SPS, that is, the political speech under the title of 'Tahun Berdikari' ${ }^{\text {"7 }}$ It was delivered by Soekarno on August $17^{\text {th }} 1945$.

The SPS 'Tahun Berdikari' was selected for several reasons. The first reason, Soekarno himself stated that the speeches of August $17^{\text {th }}$ were very important (Siswo, 2014). Among the speeches, 'Tahun Berdikari' was the most important speech. It was the only speech that contains a summary of all the August speeches, that Soekarno delivered from August, $17^{\text {th }} 1945$ - August, $17^{\text {th }}$ 1959. In other words, it incorporates the complete ideology of SPL. The second reason is described as follows. In 1965, Indonesia faced critical times as the communist party maneuvered to kill a number of Indonesian generals. This was followed by the tragedy of large-scale killings and civil unrest which occurred over several months, targeting communist sympathizers, ethnic Chinese and alleged leftists, often at the instigation of the armed forces and government (Melvin, 2017). Hermeneutically, as the president, with evidence of foresight, Soekarno appeared to feel and sense the crisis before the tragedy happened. For sure, he constructed and delivered his best political speech in that year. That is why SPS 'Tahun Berdikari' is selected to be a data source.

In analyzing the data, we applied qualitative research technique that was based on grounded theory. The theory is a logically consistent set of data collection and analytic procedures aimed to develop a theory (Charmaz, 2014). It is a kind of inductive strategy for analyzing data. The researchers started with an individual case that is SPS 'Tahun Berdikari', and developed progressively more abstract conceptual categories to build a proposal of how to reveal ideology in political language.

A major contribution of the grounded theory method is that it provides rigorous procedures for researchers to check, refine and develop their ideas and intuitions about the data (Bryan \& Charmaz, 2007). In the current research, we

5 (Indonesian: Komisi Pemberantasan Korupsi), abbreviated as KPK, is a government agency established to fight corruption. In English it is called Indonesia's Corruption Eradication Commission

${ }^{6}$ Soekarno was a great Indonesian politician as well as the founder and the first president of Indonesia.

${ }^{7}$ Tahun Berdikari is a speech of Soekarno that delivered in August $17^{\text {th }} 1965$. In English, Tahun Berdikari is translated "Standing On Their Own Feet".

Latupeirissa, D. S., Laksana, I. K. D., Artawa, K., \& Sosiowati, I. G. A. G. (2019). Revealing ideology of political speech. International Research Journal of Management, IT and Social Sciences, 6(2), 79-91. https://doi.org/10.21744/irjmis.v6n2.654 
develop an idea about procedures of revealing ideology in a text. Text may be judged as domain representation, the significance of the word and experience, which is open to various interpretations (Fairclough, 1995a). The interpretation implied idea to be developed and proposed. The proposal is a kind of introductory proposal for other researchers who are interested in conducting research on discourse analysis field, especially in the area of ideology in political speech.

\section{Results and Discussions}

In this section, we present three procedures of how to reveal ideology in a political language. The procedures are described together with the analysis of data. The analysis itself acts as shreds of evidence as well as examples of applying the procedures, and the reflection for Ideology and Politics in Indonesia.

\subsection{Examining the Main Rhetorical Device(s) That Used by Politician}

Firstly, the main rhetorical device(s) used by politician needs to be examined. The rhetorical device uses words in a certain way to convey meaning or to persuade (Hernández, 2012). It can also be a technique used to evoke emotion on the part of the reader or audience (Li et al., 2016). Harris (2002), mentioned that there are 60 rhetorical devices. It is a lot of numbers to be used by politicians. Using all rhetorical devices in a single text of political speech seems impossible for a politician. However, even though a politician uses all the devices in his/her political speech, but the decision to examine is on the researcher's side. To reveal ideology, a researcher may analyze all devices or may just analyze the dominant devices.

The current paper examined only dominant rhetoric devices in SPS. It has been enough to uncover the character of the SPS' ideology. On the examination, it has been found that the main rhetorical device used by Soekarno was repetition. It appeared 206 (two hundred and six) times. This phenomenon spread in 145 segments. In other words, at least, in a segment or in each paragraph, Soekarno used more than one repetition style in his political speech.

Repetition is a major rhetorical strategy for producing emphasis, clarity, amplification, or emotional effect. It is a broad term, which is used in all languages. Tannen (2007), defines repetition as the recurrence of words and collocations of words in the same discourse. Political speech is one of the genres that uses repetition and relies on it heavily. Soekarno utilized repetition not only to echo repetition's original function, which is confirmation. Rather, He believed in its strong effect of persuasion. Therefore, Soekarno resorted to it either to convince the audience of a certain critical and political events or to propose a definite previous vision.

Using a software program of WordSmith 7, it was found the main lexicons that were repeated by Soekarno. The lexicons are 'yang', 'kita', 'Indonesia', and 'memberikan'. The presentation of the occurrence is shown in the following chart.

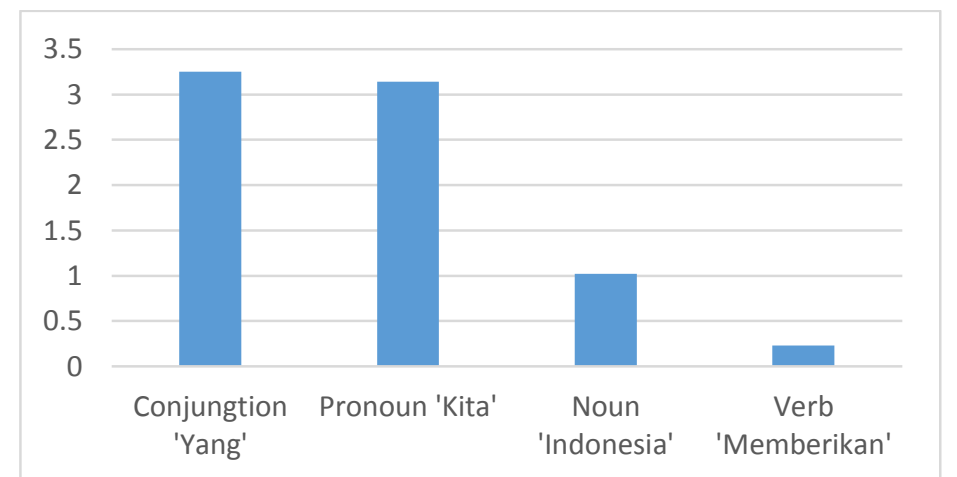

Figure 2. Chart of Lexicons that Were Dominantly Repeated by Soekarno

'Yang' was the most highly ranked lexicon that was used repeatedly by Soekarno. It occurs 383 times in SPS and occupies $3.24 \%$ of the corpus. Semantically, 'yang' is the only Indonesian conjunction word - 'that', 'who', 'which', 'where' - that acts as preposition of placement in relative clauses. It is used to explain something.

After 'yang', the personal pronoun 'kita' is the next highest ranking word used by Soekarno. 'Kita' means 'we', or ' $u s$ ' in English. It appears 371 times and occupies $2.14 \%$ of the corpus. On a different side, 'Indonesia' is the highest 
ranking noun used by Soekarno. It is used 121 times occurring in $1.02 \%$ of the corpus. The last, 'memberikan' is the highest ranking verb that was used by Soekarno. Semantically, 'memberikan' is a verb that means 'give' in English.

'Yang', 'Kita', 'Indonesia', and 'Memberikan', the words used repeatedly by Soekarno, mirror his personality. Hermeneutically, Soekarno was a politician who used language to explain. His explanations were offered because many Indonesian people in the past did not have sufficient understanding of many things. For example, they did not know about the dangers of neo-colonialism. Instead of just commanding people to fight neo-colonialism, Soekarno chose to offer explanations using 'yang'. The authors surmise that if the highest ranked word in Soekarno's lexicon is a verb, then it might be concluded that Soekarno was a politician who just commanded people.

Next, linguistic elements such as pronouns need to be examined since they are used to convey very different purposes (David, 2014). Related to the statement, current research has found a personal pronoun that was commonly used in SPS. As has been stated above, it was 'kita'. The personal pronoun 'kita' (we/ us) that was often repeated by Soekarno, hermeneutically reflects Soekarno as a politician who did not only think of himself. What he did was not only for himself but for all people's sake. Again the authors surmise, that if the personal pronoun that was most often repeated by Soekarno was 'saya/ aku' ( I ), then it might be concluded that Soekarno was a selfish politician. Even though David (2014), states that the use of the first person singular pronoun 'I' declares who is responsible while using the first person plural pronoun 'We' can have the purpose of making the status of responsibility not very clear, on the current research, the researchers deny the statement of David (2014). Soekarno was not like what David (2014), has stated. Our interpretation of the use of ' $k i t a$ ' is supported by the finding of another word, a noun, that was often repeated by Soekarno. The other noun was 'Indonesia'.

As 'Indonesia' was the highest ranked noun repeatedly used by Soekarno, it reflects the thought that most occupied Soekarno's mind. The thing that was most consistently present in Soekarno's thinking was Indonesia. Soekarno did not only think of his position. Finally, Soekarno often repeated the verb 'memberi' (give/ giving). Our other interpretation is based on the repeated verb of 'memberi' (give/ giving). Relating to the context, Soekarno often delivered speeches to motivate all Indonesian people to offer or to give everything that could be given for the sake of Indonesia. Here, Soekarno taught people to care for others. In fact, when the history of Soekarno's struggle was examined, we have found that he did not only speak or teach people to give something for the nation, but he personally demonstrated a life of offering and giving. It showed his true struggle in the political world.

Based on the analysis of SPS' main form, it can be stated that it was Soekarno's normal pattern to offer explanation to teach Indonesian people. His teaching was given for the sake of the people of Indonesia, not for his own sake (this statement is supported by the next procedure, analyzing the structure of the whole text). His teaching was mainly motivating people to give something for the betterment of the nation. On this point, the ideological value behind the speech is revealed clearly.

Other rhetorical devices need to be examined are the use of metaphors, similes, jargons, as well as the use of clauses with denotative meaning. In SPS, there were found 101 phrases and clauses that contain metaphors, jargons, and other denotative clauses. After being examined hermeneutically, those phrases and clauses could be grouped based to their own meaning, that is, (1) religious meaning, (2) meaning of struggling, and (3) ideological meaning. The groups and their percentages are shown in the following chart.

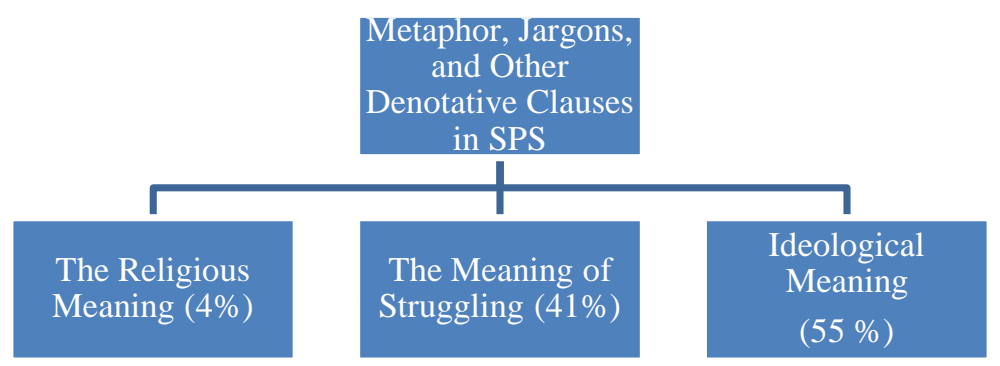

Figure 3. Diagram of SPS' Meaning and Their Percentages

Some examples of the findings are presented in the brief explanation of Text 1 , Text 2, Text 3 , and Text 4 as follows.

Text 1 (Translated)

'... in the name of the nation of Indonesia, (I) proclaimed the holy proclamation of August $17^{\text {th }} . .$. '

Latupeirissa, D. S., Laksana, I. K. D., Artawa, K., \& Sosiowati, I. G. A. G. (2019). Revealing ideology of political speech. International Research Journal of Management, IT and Social Sciences, 6(2), 79-91. https://doi.org/10.21744/irjmis.v6n2.654 
Text 2 (Translated)

'...Insyaallah, God Bless our freedom...'

In the Text 1, Soekarno used lexicon 'holy' that refers to the proclamation of Indonesia freedom. Since the context in Indonesia would only use lexicon 'holy' for a religious purpose, it is stated the Text 1 has got connotative meaning. On the other side, Text 2 displays hope as well as a prayer to God. The prayer was to ask God to bless the freedom of Indonesia. Combining Text 1 and Text 2, the connotative meaning in the phrase of 'holy proclamation' in Text 1 can be stated as a phrase with religious meaning. Evoking religious meaning in the speech is also identified when the researchers conducted the third procedure (it will be explained in the section of the third procedure). Next, Text 3 and Text 4 are displayed as follows.

Text 3 (Translated)

'...we have to be brave, be brave, be brave, like the braveness of bulls and eagles...'

Text 4 (Translated)

'...we have to be one, be one, be one, like the oneness of five fingers in a fist...'

Text 3 and Text 4 are similes that were found in SPS. In Text 3, Soekarno mentioned 'bulls and eagles'. The two animals were mentioned several times in SPS. The phenomena were symbols of something important that wanted to be evoked by Soekarno. They contained ideological values. Having analyzed deeper, Text 3 is stated as a clause with the meaning of struggle (see the explanation of 'Indonesia' as the highest noun repeated by Soekarno). On the other side, similar to Text 3, Text 4 shows how Soekarno used simile to construct ideological meaning. It is stated directly as the ideological meaning after the researchers have conducted an analysis of the whole text structure.

\subsection{Analyzing the Construction of The Whole Text}

Besides working on the analysis of rhetorical devices as well as examining 'unique' words to reveal ideology in the text, the construction of the whole text has to be analyzed as well. What is meant by 'examining the construction of the whole text' in the current research is analyzing the general structures of paragraphs/ segments. The researchers started the analysis by addressing questions (1) how many segments are those in SPS? (2) what are the main ideas of each segment? (3) what are the common topics/ dominant issues they share together? and (4) how many segments discus topic 'A', how many segments discus topic ' $\mathrm{X}$ ', and how many segments discus topic ' $\mathrm{Y}$ ' (If the common topics/ dominant issues are ' $\mathrm{A}$ ', ' $\mathrm{X}$ ', and ' $\mathrm{Y}$ ')?

On the examination, the researchers have found some important clues that will lead them to the revelation of ideology. First, there were 145 segments in SPS. Second, on the segments, there were more than 14 main ideas/ issues discussed by Soekarno. The topics were 1) unity, 2) revolution, 3) imperialism/ capitalism, 4) history of the Indonesian nation, 5) thanksgiving for many positive aspects that have been given to Indonesian people, 6) the spirit of struggling in gaining freedom, 7) the meaning of freedom, 8) do not give up in facing difficulties, 9) nationalism, 10) the spirit of independence, 11) real leadership, 12) culture, 13) spiritual braveness, and 14) the ideology of marhaenism. Third, the dominant issues were unity, revolution, and imperialism.

Soekarno discussed 'unity for Indonesian'. The theme of unity dominates $30 \%$ of the whole text. Semantically, there are 119 lexicons that related to the topic of unity as the most important thing for Indonesians. The lexicons were used to persuade people to be united. In the analysis of context, it would be explained the whyness of this persuasion. The second dominant topic that has been identified, was about revolution. The researchers have found that Soekarno constructed 39 segments speaking to speak about revolution. It features in $27 \%$ of the whole text. The general meaning of these segments is that 'revolution itself that must be sustained and continually lived out by all Indonesian people'. Both the first and second topics are repeatedly expressed in SPS. Overall, there are 204 lexicons that are semantically related to the topic of revolution. There are 164 lexicons of the word 'revolution', and 40 lexicons of the word 'revolutionary'.

The third dominant topic that has been identified, was imperialism and capitalism. The total construction of segments that speak about it was 31 . It features in $22 \%$ of the text as a whole. Semantically, there are 76 lexicons that relate to this third topic. Using the lexicons, Soekarno constructed the ideology into Indonesian people. Following is the chart of SPS' topics/ issues. 


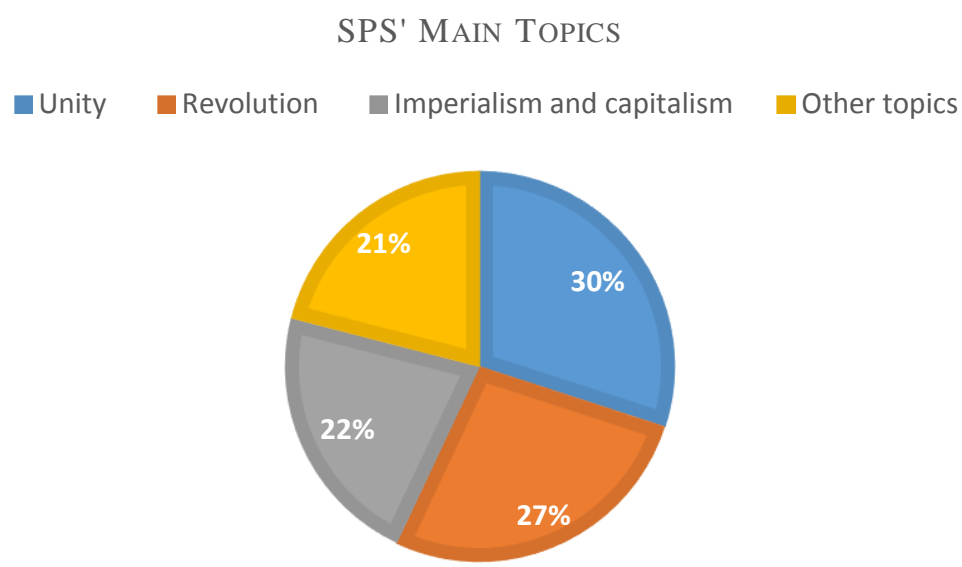

Figure 4. The Dominant Issues of SPS

Other topics, collectively comprising $21 \%$, talk about: (1) history of the Indonesian nation, (2) thanksgiving for many positive aspects that have been given to Indonesian people, (3) the spirit of struggling in gaining freedom, (4) the meaning of freedom, (5) do not give up in facing difficulties, (6) nationalism, (7) the spirit of independence, (8) real leadership, (9) culture, (10) spiritual braveness, and (11) the ideology of marhaenism. The eleven ideas above, overall, are only $1.9 \%$ of the SPL. In other words, they are not dominant in the text. The dominant ideas, or the main topics, are 'unity', 'revolution soul', and 'Imperialism and Capitalism'. Having conducted the analysis, the researchers believe that the findings of the main topics or dominant issues of SPS have led them closer to the revelation of the ideology behind SPS.

Furthermore, it is also found that there is connectivity between the finding of rhetorical devices use and the finding of dominant issues in SPS. The connectivity is shown on the following figure (5).

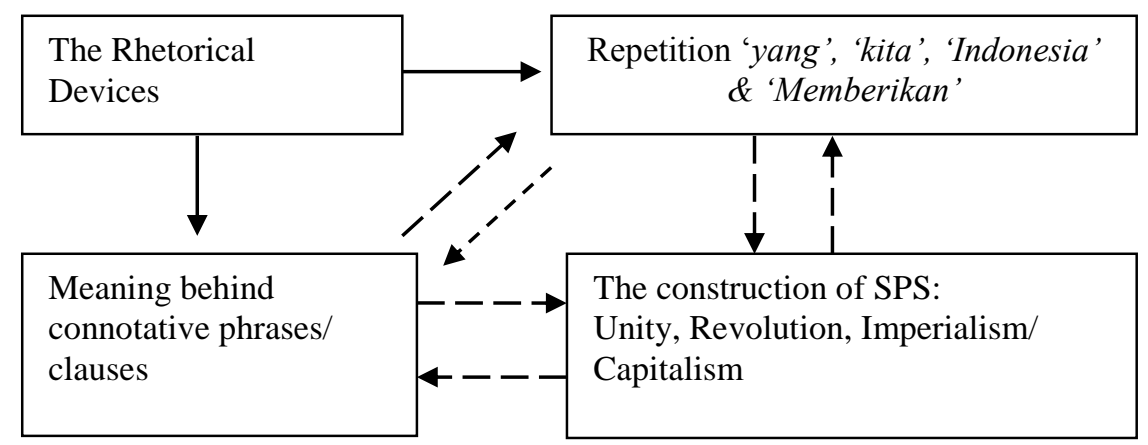

Figure 5. Connectivity among rhetorical devices in SPS and construction of SPS

The analysis of SPS construction supports the interpretation of rhetorical devices used by Soekarno in his speech. The explanation about the common repetition of conjunction 'yang', 'kita', 'Indonesia' and 'Memberikan', that has been presented above, is supported by the findings that Soekarno constructed SPS with aims of spreading thoughts about unity and revolution. On the other sides, the findings of meaning behind connotative phrases/ clauses/ metaphors/ jargons/ similes support the explanation about both repetition phenomena and text construction to fight imperialism/ capitalism.

Soekarno used repetition of lexicon 'yang' to explain that (1) unity is important, (2) revolution is needed, and (3) both imperialism and capitalism are dangerous for Indonesia. Using the repetition of ' $k i t a$ ', he persuaded Indonesian people to be united. Furthermore, with some connotative phrases/ clauses as well as metaphors, jargons, and similies, he persuaded people to support his three main ideas of SPS. It shows that the three main ideas are important. On this level, they can be stated as the ideology of SPS. To ensure the statement, the researchers reviewed the context of the situation and the background of Soekarno.

Latupeirissa, D. S., Laksana, I. K. D., Artawa, K., \& Sosiowati, I. G. A. G. (2019). Revealing ideology of political speech. International Research Journal of Management, IT and Social Sciences, 6(2), 79-91. https://doi.org/10.21744/irjmis.v6n2.654 


\subsection{Reviewing Context of Situation and the Background of the Politician}

The context of the situation when a political speech was delivered and the background of the politician who produced the speech have to be reviewed. This is important to know the whatness and the whyness. Based on the context and the background, the ideology will be revealed clearer. Following is the brief presentation about the context when SPS 'Tahun Berdikari' was delivered and the background of Soekarno as the speaker.

Soekarno was born in 1901 of a Javanese father and Balinese mother. At an early age, the family moved to Modjokerto, where his father taught school. Soekarno's adequate knowledge of Dutch made it possible for him to enter the European elementary school. In 1916 he enrolled at a high school in Surabaya. During this period he lived with H. O. S. Tjokroaminoto, a prominent Islamic leader and head of Sarekat Islam. The 5 years (1916-1921) Soekarno spent in Surabaya were most important in his future intellectual and political development, for here he came in contact with prominent Indonesian nationalists and with Dutch socialists.

In 1920, the left wing of the Sarekat Islam split away and formed the Indonesian Communist Party (PKI). The following year Soekarno entered the Institute of Technology in Bandung, from which he graduated in 1926 as an engineer. He embarked on a political career, publishing a series of articles in which he endeavored to reconcile the two contending factions by trying to show that Islam and communism (socialism) were not incompatible. The rallying force for Indonesian independence was to be nationalism, aggressively pursued. The enemies common to all groups in Indonesia were, in his judgment, imperialism, and capitalism, both exemplified in the Dutch.

Soekarno's belief that a misunderstanding had brought about the conflict between Islam and communism was first presented in 1926 and continued into the sixties. With the founding of the Indonesian Nationalist Party (PNI) in 1927 and the earlier banning of the PKI as a result of the Madiun revolt in 1926, Soekarno's task of unifying the various nationalist groups was made much easier. His influence and fame were greatly enhanced by his trial in 1930. As a result of anti-colonialist utterances, Soekarno had been accused by the government of the Dutch Indies of treason and sentenced to 4 years in prison, only 2 of which he had to serve. Shortly after his release Sukarno was arrested again and was exiled to Ende on the island of Flores in February 1934.

In June 1945 Soekarno headed the very important preparatory Committee for Indonesian Independence. Soekarno indicated clearly that his goal had always been, and still was, Indonesia's independence. On this occasion, he set forth in eloquent terms the Pancasila, or Five Pillars: nationalism, internationalism, democracy, social justice, and belief in God. On August 17 ${ }^{\text {th }}, 1945$, Soekarno proclaimed Indonesia's independence, and he became the first president of the new Republic of Indonesia (Sukarno, 2019).

On Soekarno's brief biography, it is known that (1) Soekarno's mother was a Hinduism Girl, (2) Soekarno was brilliant, (3) Soekarno had ever studied from different politicians such as Islamic politicians, Socialist politicians, and Nationalist politicians, and (4) Soekarno fought for the independence of Indonesia. Those four facts support the interpretation about the ideology of SPS, that is 'unity as the most important thing for Indonesians', 'revolution must be in the Indonesian soul', and 'Imperialism and Capitalism as Indonesia's main enemy'. As the one who ever studied from different political Parties, and as the one who was raised as a Muslim by a mother with Hinduism background, Soekarno had understood that diversity is not a problem. Therefore, one of his value was unity in diversity.

In the other hand, as have been stated above, Soekarno with his intelligence had taught people in Indonesia to keep fighting for revolution and opposing imperialism/ capitalism. His advice, that used repetition lexicon 'memberi' (give), was not to manipulate people. In his background, Soekarno had shown that acted to give himself for fighting. He fought for the unity of Indonesia, for revolution, and for opposing imperialism.

The background of the situation at the time, according to the researchers' view, needed the ideology constructed by Soekarno. Unity as the most important thing for Indonesian people was constructed by Soekarno for several reasons. Historically, Indonesia is a multi-racial nation, a multi-religious nation, as well as a multi-cultural nation (Sa'idi, 2017). This situation makes it easy for the nation to be divided (Rosana, 2017). Besides that, there were many rebellions at the time. One of them was the rebellion of the Communist Party by 1965 (only 3 months after SPS 'Tahun Berdikari' was delivered). Therefore, ideology of unity was constructed and spread by Soekarno.

The ideology of 'Imperialism and Capitalism as the main enemy of Indonesia' was important at the time. Historically, colonialism, constructed by European imperialists, has influenced the way of life of many Indonesian people (cf. King, 2016). Therefore, in his speech, Soekarno offended and denounced people who were westernized. On the other side, in the Indonesian history of the early days of independence, there were many Indonesians who were proud to speak Dutch or English compared to speaking in Indonesian. Some people tended to feel more honored if they were friends of Europeans rather than being friends of their fellow Indonesians. 
The western lifestyle adopted by Asian people, in this case, Indonesians, as already mentioned above, was destructive because it did not reflect nationalism. This is what Soekarno opposed. In the end, gradually, Indonesian people have experienced a change in their way of life. In addition, Indonesian people began to use the Indonesian language with pride, and people also began to work hard to give meaningful expression to Indonesia's independence. Gradually, Indonesians have found their real identity as Asian people.

\subsection{Novelties}

Having done the analysis, there are some novelties of this study which are presented as follows. First, procedures in revealing the ideology of political language have been presented as an introductory idea. It can be a new technique for uncovering ideology behind political text. Based on our view, it was the first simple technique in revealing ideology of political speech text. The technique is shown in the following figure (6). The procedures presented in figure 6 are enrichment for the future study of text, especially of political speech text.

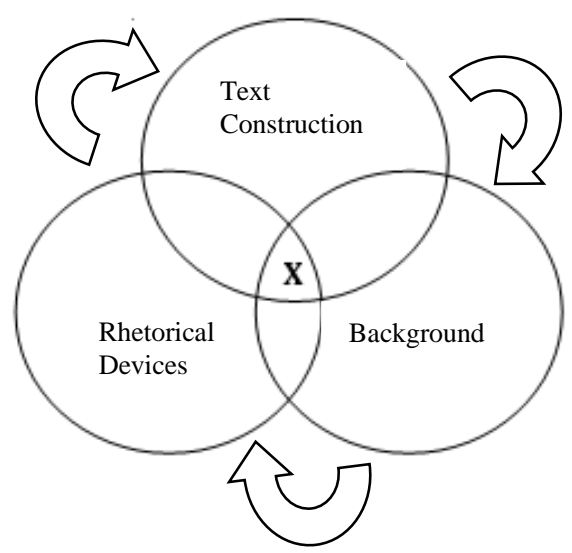

Figure 6. Procedures of Revealing Ideology in Political Speech

Second, in the history of Indonesia, there is no one who has ever stated that the most important text of SPS is 'Tahun Berdikari'. Based on our examination, we have found that 'Tahun Berdikari' is the most important SPS. The reasons for this statement have been stated in the 'Research Method' section of the current paper. This is also a novelty of the current study. Third, there is a belief among Indonesian People that Marhaenism and Nasakom were the main ideology of Soekarno (Wibowo, 2005; Kuswono, 2016; Winata, 2017). Based on the current research's finding, we have found that the belief was not correct. The Marhaenism and Nasakom were only 'branch' of three main ideologies, that is, 'unity as the most important thing for Indonesians', 'revolution must be in the Indonesian soul', and 'Imperialism and Capitalism as Indonesia's main enemy'. Furthermore, the ideologies are valuable for the Indonesia context todays because the nation itself is being threatened by radicalism ideology. The third phenomena is the last novelty of the current study.

\section{Conclusion}

Having the analysis above, we conclude that the procedures for revealing ideology - namely 1) by analyzing the main rhetorical devices that are used by the politician, 2) by analyzing the construction of the whole text, and 3) by reviewing the context of the situation and the background of the politician - are applicable to reveal ideology behind political speech text. As the results of applying the procedures, it was found that the ideologies of Soekarno's political speech were 'unity as the most important value for Indonesia', 'revolution as the soul of Indonesia' and, 'imperialism as the main enemy of Indonesia'. The ideologies are valuable reflection for the Indonesia context. Society, especially Indonesian people, should reflect the positive ideology that have been planted by Soekarno as the founding father of their nation.

Latupeirissa, D. S., Laksana, I. K. D., Artawa, K., \& Sosiowati, I. G. A. G. (2019). Revealing ideology of political speech. International Research Journal of Management, IT and Social Sciences, 6(2), 79-91. https://doi.org/10.21744/irjmis.v6n2.654 
The novelties of the current study are (1) the simple procedures to reveal political speech in a text, that have been applied in the current study, is an enhancement of future text study; (2) the most important speech of Soekarno's political speech is "Tahun Berdikari" speech as the speech itself contains complete ideologies of Soekarno, and (3) the main ideologies of SPS are valuable for the nation of Indonesia.

Conflict of interest statement and funding sources

The authors declare that they have no competing interest.

Statement of authorship

The authors have a responsibility for the conception and design of the study. The authors have approved the final article.

Acknowledgments

This work was supported by the Research Fund provided by Ministry of Research, Technology and Higher Education of Indonesia. 


\section{References}

Arigi, F. (2019). BIN Sebut Gagasan Khilafah Hidup di Pendukung \#2019GantiPresiden. Accessed on March $1^{\text {st }}, 2019$. Available at https://nasional.tempo.co/read/1121621/bin-sebut-gagasan-khilafah-hidup-di-pendukung2019gantipresiden/full\&view=ok.

Bryant, A., \& Charmaz, K. (Eds.). (2007). The Sage handbook of grounded theory. Sage.

Charmaz, K. (2014). Constructing grounded theory. Sage.

Corruption Perceptions Index. (2017). Indonesia Corruption index by Transparency International. Accessed in March, $2^{\text {nd }}$ 2018. Available at https://tradingeconomics.com/indonesia/corruption-index.

David, M. K. (2014). Language, power and manipulation: the use of rhetoric in maintaining political influence. Frontiers of Language and Teaching, 5(1), 164-170.

Erikson, R. S., \& Tedin, K. L. (2015). American public opinion: Its origins, content and impact. Routledge. https://doi.org/10.4324/9781315664866

Fairclough, N. (1989). Language and Power\| Longman. https://doi.org/10.4324/9781315834368

Fairclough, N. (1995). (1995a) Media Discourse. London: Edward Arnold.

Fairclough, N. (2001). Language and power. Pearson Education.

Fairclough, N. (2003). Analysing discourse: Textual analysis for social research. Psychology Press.

Fairclough, N. (2005). Peripheral vision: Discourse analysis in organization studies: The case for critical realism. Organization studies, 26(6), 915-939. https://doi.org/10.1177\%2F0170840605054610

Fairclough, N. (2007). Discourse and contemporary social change (Vol. 54). Peter Lang.

Fairclough, S. H., \& Venables, L. (2006). Prediction of subjective states from psychophysiology: A multivariate approach. Biological psychology, 71(1), 100-110. https://doi.org/10.1016/j.biopsycho.2005.03.007

Fengjie, L., Jia, R., \& Yingying, Z. (2016). Analysis of the Rhetorical Devices in Obama's Public Speeches. International Journal of Language and Linguistics, 4(4), 141-146. https://doi.org/10.11648/j.ij11.20160404.11

Firmansyah, W. (2018). Ketua DPP HTI: Pendukung Kami Makin Banyak. Accessed in March, $1^{\text {st }}$, 2019. Available at http://www.tribunnews.com/nasional/2018/05/09/ketua-dpp-hti-pendukung-kami-makin-banyak?page=3.

Galamas, F. (2015). Terrorism in Indonesia: an overview. Research Papers, 4, 2015.

Harris, R. (2002). A handbook of rhetorical devices. Salt Lake City, UT: Virtual Salt.

Hernández-Guerra, C. (2012). Outstanding rhetorical devices and textuality in Obama's speech in Ghana, Africa. Open Journal of Modern Linguistics, 2(03), 97.

Jones, S. (2015). ISIS in Indonesia. Southeast Asian Affairs, 2015(1), 154-163.

King, V. T. (2016). Conceptualising culture, identity and region: Recent reflections on Southeast Asia. Pertanika. Journal of Social Sciences and Humanities, 24(1), 25-42.

Kuswono, K. (2016). Marhaenism: Social Ideology Create by Sukarno. HISTORIA Jurnal Program Studi Pendidikan Sejarah, 4(2), 119-130. http://dx.doi.org/10.24127/hj.v4i2.549

Latupeirissa, D. S., Laksana, I. K. D., Artawa, K., \& Sosiowati, I. G. A. G. (2018). Repetition in Indonesian political language. International journal of linguistics, literature and culture, 4(6), 72-80. https://doi.org/10.21744/ijllc.v4n6.427

Liow, J. C. (2014). ISIS goes to Asia. Foreign Affairs, 19.

McLellan, D. (1986). Ideology. Minneapolis: Univ. Minn. Press

Melvin, J. (2017). Mechanics of Mass Murder: A Case for Understanding the Indonesian Killings as Genocide. Journal of Genocide Research, 19(4), 487-511. https://doi:10.1080/14623528.2017.1393942.

Mohamed Osman, M. N. (2010). Reviving the caliphate in the Nusantara: Hizbut Tahrir Indonesia's mobilization strategy and its impact in Indonesia. Terrorism and Political Violence, 22(4), 601-622. https://doi.org/10.1080/09546553.2010.496317

Rosana, E. (2017). Eksistensi pancasila sebagai kontrak sosial umat beragama. Jurnal tapis, 13(2), 1-17.

Sa'idi, R. (2017). Urgensi menjaga kemajemukan dan toleransi dalam era demokrasi. Jurnal tapis, 13(2), 74-90.

Siswo, I. (2014). Panca azimat revolusi: tulisan, risalah, pembelaan, \& pidato Sukarno 1926-1966. KPG (Kepustakaan Populer Gramedia).

Sukarno. (2019). Encyclopedia of World Biography. Accessed on February 4th, 2019. Available at Encyclopedia.com:https://www.encyclopedia.com/history/encyclopedias-almanacs-transcripts-and-maps/sukarno.

Tannen, D. (2007). Talking voices: Repetition, dialogue, and imagery in conversational discourse (Vol. 26). Cambridge University Press.

Thomans, L., \& Wareing, S. (1999). Language, Society and Power.

Latupeirissa, D. S., Laksana, I. K. D., Artawa, K., \& Sosiowati, I. G. A. G. (2019). Revealing ideology of political speech. International Research Journal of Management, IT and Social Sciences, 6(2), 79-91. https://doi.org/10.21744/irjmis.v6n2.654 
Tim Penyusun Laporan Tahunan KPK 2016. (2016). Accessed on March, 1 $1^{\text {st }}$ 2019. Available at https://www.kpk.go.id/images/Laporan\%20Tahunan\%20KPK\%202016\%20Bahasa\%20Indonesia.pdf

Wibowo, Y. S. (2005). Marhaenisme: ideologi perjuangan Soekarno. Buana Pustaka.

Wilson, T. (Ed.). (1990). Confocal microscopy (Vol. 426, pp. 1-64). London: Academic press.

Winata, L. (2017). Nasakom Sebagai Ideologi Negara Tahun 1959-1965. Avatara, 5(3). 
Biography of Authors

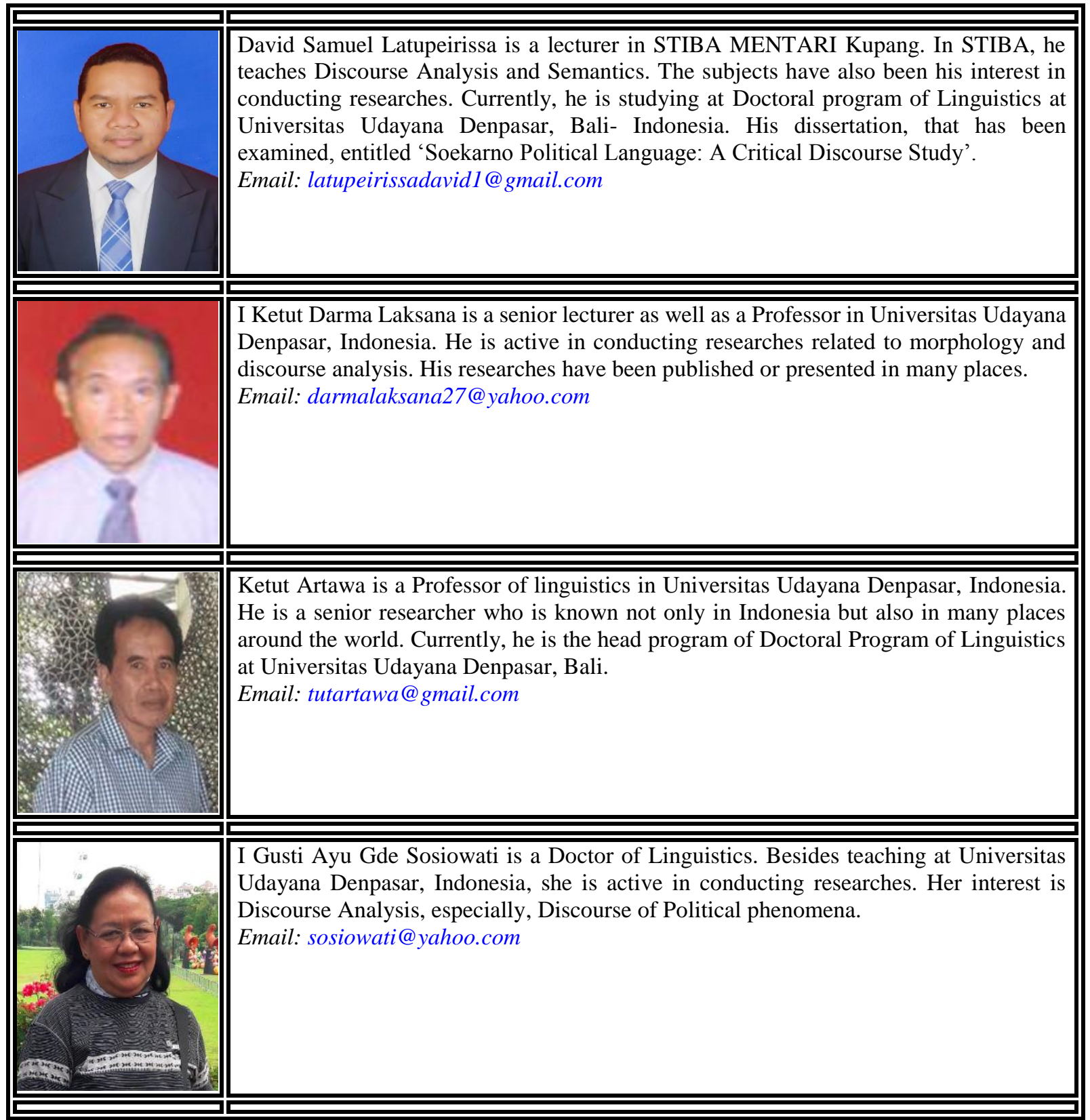

Latupeirissa, D. S., Laksana, I. K. D., Artawa, K., \& Sosiowati, I. G. A. G. (2019). Revealing ideology of political speech. International Research Journal of Management, IT and Social Sciences, 6(2), 79-91. https://doi.org/10.21744/irjmis.v6n2.654 